International Research Journal of Management, IT \& Social Sciences
Available online at https://sloap.org/journals/index.php/irjmis/
Vol. 5 No. 5, September 2018, pages: 54 60
ISSN: 2395-7492
https://doi.org/10.21744/irjmis.v5n5.288

\title{
Classroom Action Research Practices of State High School Teachers in Bali Province
}

\begin{tabular}{|c|c|}
\hline & $\begin{array}{r}\text { Wayan Maba } \\
\text { Ida Bagus Ketut Perdata } \\
\text { I Gusti Ngurah Nila Putra }\end{array}$ \\
\hline rticle history: & Abstract \\
\hline $\begin{array}{l}\text { eceived: } 10 \text { July } 2018 \\
\text { lccepted: } 30 \text { August } 2018 \\
\text { ublished: } 16 \text { September } 2018\end{array}$ & $\begin{array}{l}\text { The general purpose of this study was to find out the level of difficulty in } \\
\text { preparing Classroom Action Research (CAR) Proposals, implementation and } \\
\text { report writing of classroom action research conducted by state high school } \\
\text { teachers in Bali Province. The present study was designed for two years, the } \\
\text { study adopted the 4D model (Define, Design, Develop, and Disseminate). The } \\
\text { first year (2018) was defined as the phase of Define and Design, which aims }\end{array}$ \\
\hline $\begin{array}{l}\text { Keywords: } \\
\text { Classroom Action; } \\
\text { iigh School; } \\
\text { ractices; } \\
\text { esearch; } \\
\text { eachers; }\end{array}$ & $\begin{array}{l}\text { to design CAR proposals in line with the Lesson Plan (LP), the implementation } \\
\text { of CAR by state high school teachers and report writing linear with List of } \\
\text { Proposed Establishment of Credit (LPEC). The second year (2019) was the } \\
\text { Development and Dissemination phase. The activities in this phase were (a) } \\
\text { enhancing the development and improvement of CAR of state high school } \\
\text { teachers in accordance with the proposal model, the CAR implementation } \\
\text { model designed based on LP and CAR report model through Focus Group } \\
\text { Discussion (FGD) which was attended by High School Teachers, High School } \\
\text { Principals, High School Supervisors, LPEC High School Teachers Team, and } \\
\text { the CAR participants from the Department of Education and Sport, Bali } \\
\text { Province. The results of the second year research were the CAR proposals were } \\
\text { linear with teachers' LP, Classroom LP implementation, learning schedule, } \\
\text { and CAR report writings were linear with LPEC and publication on } \\
\text { international journal and textbook writings. }\end{array}$ \\
\hline
\end{tabular}

Author correspondence:

Wayan Maba,

Post Gradute Program, Universitas Mahasaraswati Denpasar, Bali, Indonesia

Email address: wayanmaba.unmas@gmail.com

${ }^{\text {a } U n i v e r s i t a s ~ M a h a s a r a s w a t i ~ D e n p a s a r, ~ B a l i, ~ I n d o n e s i a ~}$

b Universitas Mahasaraswati Denpasar, Bali, Indonesia

${ }^{\mathrm{c}}$ Universitas Mahasaraswati Denpasar, Bali, Indonesia 


\section{Introduction}

Education is one of the most important aspects to be nurtured in order to be able to compete globally. Without having a good education, it will be difficult to keep up with international development (Maba, 2017; Nguyen, 2011). National education is a conscious and planned effort to realize the learning atmosphere and learning process so that students actively develop their potential to have religious spiritual strength, self-control, personality, intelligence, noble character, and skills needed by the students themselves, the society, and the nation. Implementing education and learning in the classroom, in the laboratories or practice in the field are teachers' responsibility structured and tiered in formal education units, namely primary education, secondary education and higher education (Beane,1997; Maba, 2017). The main tasks and functions of teachers in formal High School Education Unit are to carry out face-to-face learning in the classroom, practice in the laboratory, or practice in the field through the interaction process of students with teachers and learning resources in a learning environment. Teacher learning activities in schools must be based on the current curriculum. The curriculum is a set of plans and arrangements regarding the objectives, content, and teaching materials and the methods used as guidelines for the implementation of learning activities to achieve the goals of education in high schools (Mantra, 2017; Maba, 2017).

A teacher has a very important and strategic role in carrying out the learning process in the classroom, in the laboratory, or in the field. The learning process conducted with the aims to realize higher quality education outcomes (Murdoch, 1998). In order for the learning process to be more optimal, the obligation for each teacher is to have professional competencies which include pedagogic competencies, personality competencies, social competencies and professional competencies obtained through professional education (Maba \& Mantra, 2018). Teachers must have academic qualifications and competence as agents of learning, physical and spiritual health, as well as having the ability to realize the goal of national education. Academic qualification is a minimum level of education, namely Bachelor of Education, which must be fulfilled by a teacher as evidenced by a relevant certificate or certificate of expertise in accordance with the prevailing laws and regulations (Maba, Perdata, Astawa, 2017).

In addition to pedagogic competence, personal competence, social competence and professional competence (Maba \& Mantra, 2018), a competency that is required by teachers is to carry out classroom action research (CAR). This competency is one of the most important competencies for teachers as reflective actions to improve the quality of learning (Dowden, T. (2007). The reflective actions are further elaborated into the competence of their respective subject teachers in which each teacher must 1) reflect on the learning being carried out, 2) utilize the results of reflection for the improvement and development of learning, and 3) conduct classroom action research (CAR) to improve the quality of learning. Therefore professional competencies are also the teachers'ability to conduct classroom action research (Maba, 2017). Based on pedagogic and professional competence of high school teachers, both in specialization in mathematics and natural sciences, in the specialization of the social sciences and in specialization in language and culture must develop professionalism in a sustainable manner in the form of classroom action research (CAR) which is carried out simultaneously with the learning process in accordance with the learning schedule issued by each high school. Every civil servant (CS) teacher is a State civilian apparatus has the obligation to implement earnestly in carrying out the main duties and functions as subject teachers namely to carry out learning to the maximum extent in each subject taught both in mathematics and natural sciences, in the specialization of the social sciences and in the specialization of language and culture. Teachers can carry out their obligations to the fullest determined by the discipline factor (Calhoun, 1994; Mantra, 2017).

With the existence of work discipline, the teachers are able to maintain their performance. The teacher is a professional position which is very instrumental position in formal education (Gabriel, 2005; Mantra, 2017). Teachers can be said to occupy a very strategic position in the management of the learning process in formal education (Danielson, \& McGreal, 2000). Teachers, who design, direct and manage the teaching and learning process in order (to) achieve the goals that have been set, to fulfill the welfare of their students. In that context, the teacher is not only fostering students to be able to master science cognitively, but further than that is to be able to foster the humanitarian value of their students' subjects (Maba \& Mantra, 2018; Whitaker, 2004).

Each teacher must improve the discipline to carry out the main tasks and functions at the beginning of the semester preparing the lesson plan (LP) based on the 2013 curriculum in high school according to the subjects taught with the stages: a) analyzing the core competencies namely spiritual attitude meaning human relations with almighty God, the two core competencies namely social attitudes mean human relations with human beings that animates these three competencies, namely knowledge (theory) and core competencies, namely skills or practices, b) and outlining three core competencies into basic competencies (Maba \& Mantra, 2018; Newmann, Smith, Allensworth, \& Bryk, 2001).

Maba, W., Perdata, I. B. K., \& Putra, I. G. N. N. (2018). Classroom action research practices of state high school teachers in Bali province. International Research Journal of Management, IT and Social Sciences, 5(5), 54-60.

https://doi.org/10.21744/irjmis.v5n5.288 
After the translation of the three basic competencies and a number of indicators, the next step is the teacher determines references in the form of learning resources holding the teacher including accredited journal articles or international journals. Based on the current regulatory analysis and reference analysis or required learning resources; then each teacher prepares lesson plans (LP) no later than one day before the school learning schedule. Along with the preparation of the lesson plan (RPP), each teacher is obliged to plan classroom action research (CAR) which begins with preparing a classroom action research proposal, conducting classroom action research together with the implementation of the lesson. Thus the main task and function of the teacher in carrying out the learning process at school are to simultaneously carry out the learning process and also carry out classroom action research.

The results of the national evaluation conducted by the government in the form of the National Examination (NE) for high school students showed that the average national examination for all subjects was still not encouraging. National Academic Year 2017/2018 Test Results showed that the quality of educational outcomes in all educational units, especially in High Schools in Bali Province were still not as expected because they have not been able to achieve the national minimum completeness criteria of $75 \%$ for the average National Examination. There are several decisive factors occurred. One of which is the quantity of education and quality of classroom action research (CAR) conducted by the teachers.

Based on the description above, it could be summed up that teachers have low competence in conducting classroom action research (CAR), therefore teachers have unfavorable impacts on increasing the level of position and have the low capability in improving students' learning. This proves that teacher professional development has not been able to make teachers attain the established criteria to create the improvement of the quality of educational outcomes as the expectations. The low quantity teaching and quality of classroom action research (CAR) by the teachers are inseparable from the academic qualifications and competence of other school stakeholders. It is merely due to the teachers'low understanding and low ability to perform perfectly according to the applicable regulation.

\section{Materials and Methods}

This study was designed for two years, this study adopted the 4D model theory namely Define, Design, Develop and Disseminate (Thiagarajan et al., 1974). The first year (2018) is defined as the Define and Design phase, conducted to practice teacher to design CAR proposal which is in accordance with lesson plans, classroom schedule, and classroom practices. Second year (2019) is the Develop and Disseminate phase, the activities in this stage are (a) Develop namely the development and the improvement of the classroom action research proposal models, the classroom action research implementation based on the posed models in conjunction with the implementation of the lesson plan and classroom action research report writing through the Focus Group activities Discussion (FGD) which was attended by high school teachers, high school principals, high school supervisors, high school credits points teams, and staff of Education and Sport Department in Bali.

\section{Results and Discussions}

This study was conducted for the duration of two years to intensively analyzed teachers' competence in classroom action research practices. A thorough investigation was carried out to reveal the reveal the required valid and reliable data. In the First year (2018) was defined as the Define and Design phase which aims to design classroom action research proposals linear with lesson plan, class schedule and report writing linear with List of Proposed Establishment of Credit (LPEC) in order that teachers are able to obtain the highest professional rank of IV/b up to IV/e . Activities in the first year were (a) Define, in which conducting needs analysis, preparation of Classroom Action Research linear with Lesson Plan models, determination of research samples, implementation of research, a recapitulation of research data and analysis of research data. (b) Design namely designing Classroom Action Research linear with teachers' proposals, linear with lesson plan implementation in class or in the laboratory according to class schedule and report writing linear with List of Proposed Establishment of Credit (LPEC), (c) expert validation for teachers' Classroom Action Research. The results of the first year research were published in the form of a scientific article in International Journal.

A needs analysis and a questionnaire for the implementation of Bali Province state high school teachers which include a) preparation of the CAR proposals include: title, background, problem formulation, variable description, research design, and 15 design cycles, b) the implementation of CAR linear with teachers' implementation of lesson 
plan in the classroom or in the laboratory accordingly lesson schedule includes: pre-activity, main activity and closing activity which covers 11 points, c) writing reports for CAR to complete List of Proposed Establishment of Credit (LPEC) to get higher professional rank. Questionnaires were disseminated and then analyzed to determine the level of difficulty of preparation of CAR linear with teachers' proposals, implementation of lesson plan according to the learning schedule in the classroom or in the laboratory, and report writing. Furthermore, the Design step was designing: CAR proposals, research implementation and report writing to be appropriate with a List of Proposed Establishment of Credit (LPEC).

The obtained data then anlysed using the following formula: $\mathrm{n}$ divided by x $100 \%$, By Criteria $90 \%-100 \%=$ Very High, Criteria 80\% -89\% = Height, Criteria 70\% - 79\% = Medium, 60\% - 69\% = Low, and Criteria 0\% - 59\% = Very Low. Based on the data analysis, the results of the analysis can be presented in the following table

Table 1

List of Proposed Establishment of Credit (LPEC)

\begin{tabular}{lllcc}
\hline No. & Learning Subject & \multicolumn{1}{c}{ PTK Difficulty Level } & $\begin{array}{c}\text { Certified Teacher } \\
(\%)\end{array}$ & $\begin{array}{c}\text { Non-certified Teacher } \\
(\%)\end{array}$ \\
\hline 1 & Indonesian Language & $\begin{array}{l}\text { a. Writing CAR Proposals } \\
\text { b. Implementation of CAR }\end{array}$ & $\begin{array}{c}\text { High } \\
\text { Very high }\end{array}$ & $\begin{array}{c}\text { Very high } \\
\text { Very high } \\
\text { Very high }\end{array}$ \\
& & c. Writing CAR report & High & Very high \\
2 & \multirow{3}{*}{ Mathematics } & a. Writing CAR proposal & High & Very high \\
& & b. Implementation of CAR & Very high & Very high \\
3 & English & c. Writing CAR report & High & Very high \\
& & a. Wriing CAR proposal & Very high & Very high \\
& & b. Implementation of CAR & Very high & Very high \\
\hline
\end{tabular}

Based on the table above evidently for certified Indonesian language teachers was found to experience high difficulty in writing CAR proposals linear with the lesson plan. The implementation linearity of CAR and the implementation of the lesson plan in the classroom or in the laboratory according to the lesson schedule, both teachers certified teachers and noncertified teachers experienced very high difficulties. Furthermore, in writing CAR reports for both teachers certified teachers and noncertified teachers experienced very high difficulty.

Moreover, Mathematics certified teacher's experienced high difficulty in preparing CAR proposals to be linear with a lesson plan and the implementation of CAR to be linear with the classroom or laboratory schedule. High school teachers are urged to be able to write reports to be linear with List of Proposed Establishment of Credit (LPEC) in the order they are able to increase their professional ranks. It can be said that without having the ability to write CAR proposal, appropriate CAR implementation, and correct report writing, teachers will find difficulty to increase their ranks.

Additionally certified English teachers also experienced difficulty in preparing appropriate CAR proposals and also found difficulty in carrying out classroom action research in a real classroom set in writing. The study found that both certified and noncertified teachers have experienced difficulty in designing CAR proposals, conducting it and also writing a research report. This low competence in conducting CAR simply affected their ability to complete List of Proposed Establishment of Credit (LPEC). Therefore, as a result, many teachers found difficulty to attain a higher rank in their profession.

\section{Conclusion}

The classroom action research implementation by state high school teacher in Bali Province Senior High were found to relatively low. This is due to many school teachers still experienced high difficulties in designing research proposals, conducting the CAR in the classroom and also in writing a research report. The present study revealed that the CAR implementation difficulty was experienced by Indonesian Language teachers, Mathematics teachers, and English language teachers. The implication of the inability to properly design, implement CAR and the difficulty in writing research report have made teachers found obstacles in attaining high rank as the unable to complete the List of Proposed Establishment of Credit (LPEC) in which the requirement of the higher rank establishment.

Maba, W., Perdata, I. B. K., \& Putra, I. G. N. N. (2018). Classroom action research practices of state high school teachers in Bali province. International Research Journal of Management, IT and Social Sciences, 5(5), 54-60. 
This findings simply suggest that all education stakeholders in Bali province are suggested to be more intensively upgrade their teacher's competence in designing CAR proposals, appropriate conduction of CAR and CAR reports writing. High school principals, in particular, are suggested to continually encourage their teachers to develop their competence in conducting comprehensive classroom research as an effort to promote the quality of education in high school and in the same to provide an opportunity for the teachers to obtain higher rank in the education profession. Teacher competence in conducting classroom action research certainly also enable teachers to carry out a researchbased teaching which creates a higher quality of teaching.

Conflict of interest statement and funding sources

The authors declared that they have no competing interest. The study was financed by personal funding.

\section{Statement of authorship}

The authors have a responsibility for the conception and design of the study. The authors have approved the final article.

\section{Acknowledgments}

The authors sincerely devoted their deep honest gratitude to Almighty God for all the abundance of his blessings in conducting and writing this research and this article could finally be published in the due time. The authors also expressed their gratitude to Rector of Mahasaraswati Denpasar University, the Chairman of Research and Community Empowerment of Mahasaraswati Denpasar University, the Dean of FKIP Mahasaraswati Denpasar University, the Head of Bali Provincial Education Office, state high school teachers of the Bali Province. 


\section{References}

Beane, J. A. (2016). Curriculum integration: Designing the core of democratic education. Teachers College Press.

Calhoun, E. F. (1994). How To Use Action Research in the Self-Renewing School. Association for Supervision and Curriculum Development, 1250 N. Pitt Street, Alexandria, VA 22314-1453 (Stock No. 1-94030, \$6.95).

Danielson, C., \& McGreal, T. L. (2000). Teacher evaluation to enhance professional practice. Ascd.

Dowden, T. (2007). Relevant, challenging, integrative and exploratory curriculum design: Perspectives from theory and practice for middle level schooling in Australia. The Australian Educational Researcher, 34(2), 51-71.

Gabriel, J. B. (2005). How to think as a teacher leader. Alexandria, VA: ASCD.

Maba, W. (2017). Teacher's Perception on the Implementation of the Assessment Process in 2013 Curriculum. International Journal of Social Sciences and Humanities, 1(2), 1-9.

Maba, W. (2017). Teachers' sustainable professional Development Through Classroom Action Research. International Journal of Research in Social Sciences 7 (8).

Maba, W. (2017). The Implementation of Education National Standard in the Instrument of School Accreditation of Bali Province Education Authority. International Research Journal of Engineering, IT \& Scientific Research (IRJEIS), 3(4), 1-6.

Maba, W., \& Mantra, I. B. N. (2018). The primary school teachers' competence in implementing the 2013 curriculum. In SHS Web of Conferences (Vol. 42, p. 00035). EDP Sciences.

Maba, W., Perdata, I. B. K., \& Astawa, I. N. (2017). Constructing Assessment Instrument Models for Teacher's Performance, Welfare and Education Quality. International Journal of Social Sciences and Humanities (IJSSH), 1(3), 88-96.

Mantra, I. B. N. (2016). Promoting Primary School Teachers' Competence through Dynamic Interactive Workshop and Partnership. Journal of College and University. This is an open access article under the, $2455,8028$.

Murdoch, K. (1998). Classroom connections: Strategies for integrated learning. Eleanor Curtain Publishing.

Newmann, F. M., Smith, B., Allensworth, E., \& Bryk, A. S. (2001). Instructional program coherence: What it is and why it should guide school improvement policy. Educational evaluation and policy analysis, 23(4), $297-321$.

Nguyen, M. T. T. (2011). Learning to communicate in a globalized world: To what extent do school textbooks facilitate the development of intercultural pragmatic competence?. RELC Journal, 42(1), 17-30.

Thiagarajan, S. (1974). Instructional development for training teachers of exceptional children: A sourcebook.

Whitaker, T. (2004). What great teachers do differently: Fourteen things that matter most. Larchmont, NY. Eye on Education, Inc.

Maba, W., Perdata, I. B. K., \& Putra, I. G. N. N. (2018). Classroom action research practices of state high school teachers in Bali province. International Research Journal of Management, IT and Social Sciences, 5(5), 54-60. 


\section{Biography of Authors}

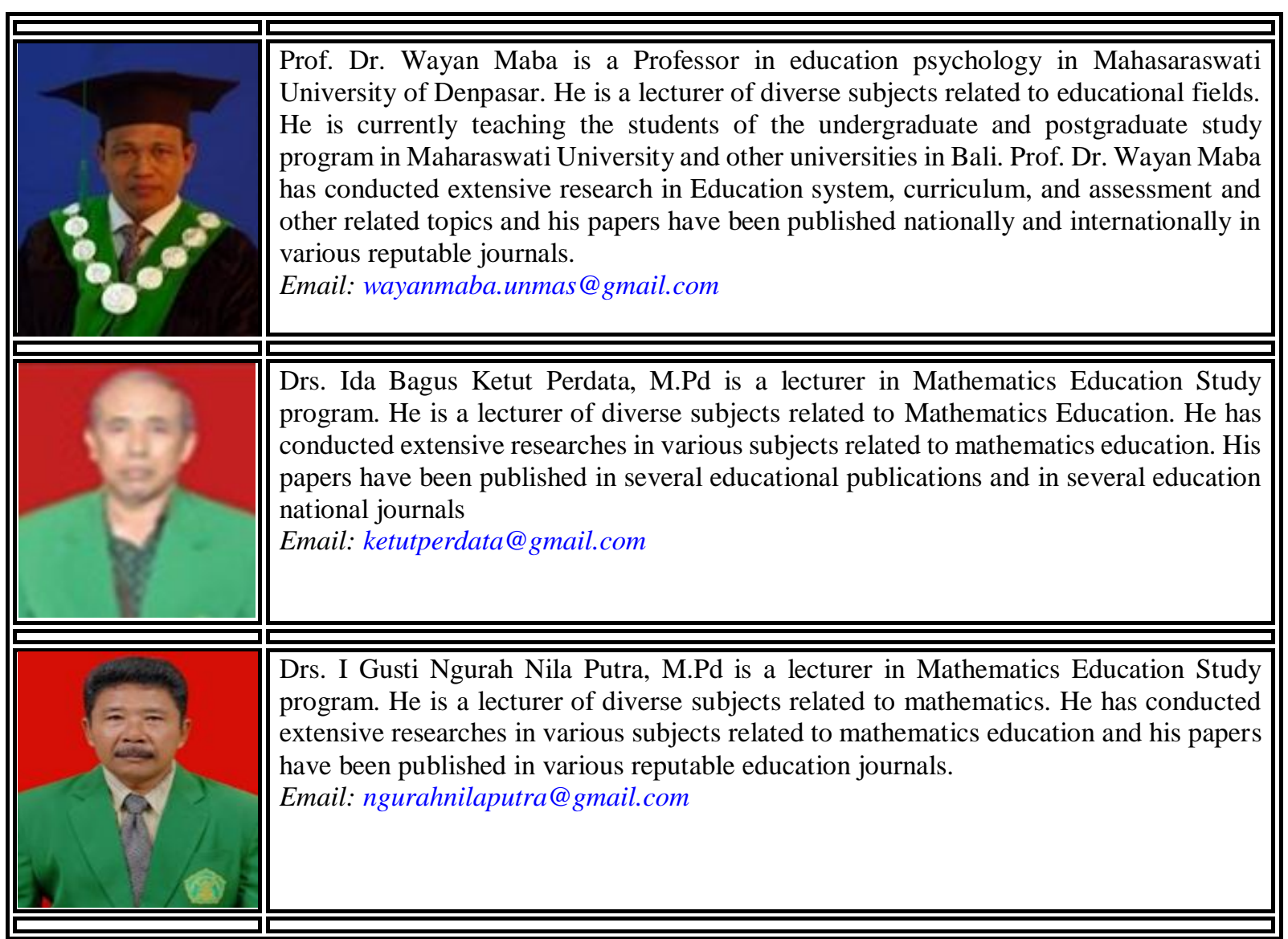

